\title{
Induction of Systemic Resistance in Plants by Biochar, a Soil-Applied Carbon Sequestering Agent
}

\author{
Yigal Elad, Dalia Rav David, Yael Meller Harel, Menahem Borenshtein, \\ Hananel Ben Kalifa, Avner Silber, and Ellen R. Graber
}

First, second, third, fourth, and fifth authors: Department of Plant Pathology and Weed Research, Institute of Plant Protection, The Volcani Center, Agricultural Research Organization, and sixth and seventh authors: Department of Soil Chemistry, Plant Nutrition and Microbiology, Institute of Soil, Water and Environmental Sciences, The Volcani Center, Agricultural Research Organization, Bet Dagan 50250, Israel.

Accepted for publication 12 May 2010.

\begin{abstract}
Elad, Y., Rav David, D., Meller Harel, Y., Borenshtein, M., Ben Kalifa, H, Silber, A., and Graber, E. R. 2010. Induction of systemic resistance in plants by biochar, a soil-applied carbon sequestering agent. Phytopathology 100:913-921.

Biochar is the solid coproduct of biomass pyrolysis, a technique used for carbon-negative production of second-generation biofuels. The biochar can be applied as a soil amendment, where it permanently sequesters carbon from the atmosphere as well as improves soil tilth,

pest (Polyphagotarsonemus latus Banks) on pepper. Levels of 1 to 5\% biochar in a soil and a coconut fiber-tuff potting medium were found to be significantly effective at suppressing both diseases in leaves of different ages. In long-term tests (105 days), pepper powdery mildew was significantly less severe in the biochar-treated plants than in the plants from the unamended controls although, during the final 25 days, the rate of disease development in the treatments and controls was similar. Possible biochar-related elicitors of systemic induced resistance are discussed.
\end{abstract} nutrient retention, and crop productivity. In addition to its other benefits in soil, we found that soil-applied biochar induces systemic resistance to the foliar fungal pathogens Botrytis cinerea (gray mold) and Leveillula taurica (powdery mildew) on pepper and tomato and to the broad mite
Additional keywords: induced systemic resistance, systemic acquired resistance.
As a result of growing concern over global climate change caused by manmade, anthropogenic greenhouse gas emissions, there is a worldwide drive to shift from a petroeconomy fueled by fossil carbon to an economy fueled by renewable energy resources, including biomass (35). Pyrolysis, the direct thermal decomposition of biomass in the absence of oxygen to solid (biochar, or charcoal), liquid (bio-oil), and gas (syngas) bioenergy products, is one of the tools suggested to help drive this paradigm shift $(30,31,35)$. Being an exothermic process, pyrolysis of biomass produces more energy than is invested in the heating process (52). The liquid and gaseous co-products are utilized for energy or chemicals, whereas the biochar is applied to the soil, where its turnover is so slow (half-life of hundreds to thousands of years) that $\mathrm{C}$ is considered to be permanently removed from the atmosphere $(30,32)$. As such, pyrolysis of biomass and soil amendment by biochar is a carbon-negative process. Importantly, biochar additions to soil have been shown to significantly improve soil tilth, nutrient retention and availability to plants, and crop productivity $(7,19,33,51)$.

Improved crop response as a result of biochar amendment can be attributed to its nutrient content and to several indirect effects, including increased nutrient retention $(7,19,33,51)$; improvements in soil $\mathrm{pH}(38,51)$; increased soil cation exchange capacity $(38,51)$; effects on $\mathrm{P}$ and $\mathrm{S}$ transformations and turnover $(12,13)$; neutralization of phytotoxic compounds in the soil (62); improved soil physical properties such as increased water-holding capacity (26), reduced soil strength (8), and increased soil bulk density

Corresponding author: Y. Elad; E-mail address: elady@ volcani.agri.gov.il

doi:10.1094/PHYTO-100-9-0913

(C) 2010 The American Phytopathological Society
(19); promotion of mycorrhizal fungi $(26,63)$; and alteration of soil microbial populations and functions $(42,50)$. Many of these effects are interrelated and may act synergistically to improve crop performance.

Based on the chemical, microbial, and physical improvements reported for biochar-amended soil, it could be anticipated that biochar would also have a positive impact on plant resistance to disease. However, to the best of our knowledge, there have been virtually no studies of disease suppression and resistance induced by biochar. The single published study of which we are aware, while principally concerned with the effect of arbuscular mycorrhizal fungal inoculations on asparagus tolerance to Fusarium root rot, incidentally demonstrated that biochar amendments had a suppressive effect on the soil pathogen (36). Biochar suppression of soil pathogens may stem from a myriad of mechanisms similar to those by which compost is thought to suppress soil pathogens $(24,29)$ : (i) stimulation of microbes which provide direct protection against pathogens via antibiosis, competition, or parasitism; (ii) promotion of plant growth by providing nutrients and improving nutrient solubilization and uptake; or (iii) induction of plant defense mechanisms against disease.

Induced disease resistance in plants is a physiological state of enhanced defensive capacity elicited by specific stimuli, whereby the plant's innate defenses are potentiated against subsequent challenges (56). This enhanced state of resistance is effective against a broad range of pathogens and parasites, including fungi, bacteria, viruses, and nematodes (56). The two most clearly defined forms of induced resistance are systemic acquired resistance (SAR) and induced systemic resistance (ISR) which, in model plant systems, can be differentiated by the nature of the elicitor and regulatory pathways. SAR is associated with the production of pathogenesis-related $(\mathrm{PR})$ proteins and mediated 
via a salicylic acid (SA)-dependent process. SAR develops subsequent to a localized hypersensitive reaction. ISR develops systemically in response to colonization of plant roots by plant growth-promoting rhizobacteria (PGPR) and fungi (PGPF) (57). This type of resistance does not involve expression of PR proteins and is mediated by a signaling pathway in which the phytohormones jasmonic acid (JA) and ethylene (E) play key roles (58). SAR is effective for a variety of plant species, while the ability of PGPR and PGPF to promote ISR is specific to certain plant species and genotypes (59).

Both chemical elicitors and biological elicitors (virulent, avirulent, and nonpathogenic microorganisms) can trigger SAR (56). For example, Trichoderma spp. can release compounds that induce SAR much as they elicit ISR (22). Chemical inducers of systemic resistance include the synthetic SA analogues 2,6dichloroisoniciotinic acid (INA) and acibenzolar-S-methyl (BTH) $(25,41)$, methyl jasmonate (6), chitin (44) and chitosan (5), laminarin (55), and $\beta$-aminobutyric acid (BABA) (21). Phosphate salts, silicon, amino acids, fatty acids, and cell wall fragments can also stimulate systemic resistance $(45,61,66)$, as can environmental agents such as osmotic, moisture and proton stresses, mechanical wounding, and temperature extremes $(4,65)$.

Frequently, induced disease resistance is associated with an overall heightened capacity of the plant to induce cellular defense responses upon encountering stresses (i.e., "the primed state of the plant") (54). Although the physiological and molecular mechanisms underlying primed responses are widely unknown, priming has been observed to be an integral part of both SAR and ISR. Primed plants display faster and stronger activation of cellular defense responses after pathogen challenge compared with nonprimed plants (10), including earlier oxidative burst and stronger upregulation of defense genes $(2,11)$. The priming effect is not restricted to biotic stresses but has been observed also for abiotic stresses such as salt, heat, cold, and drought (54).

The present study was designed to test whether root-zoneapplied biochar was capable of inducing systemic resistance in plants by evaluating the development of biotrophic (Leveillula taurica) and necrotrophic (Botrytis cinerea) foliar pathogens, as well as a foliar mite pest. We examined the effect of plant potting medium, biochar content, temporal and spatial effects, and longterm exposure on the ability of biochar to suppress foliar fungal infection and mite infestation of pepper and tomato plants.

Powdery mildew, caused by L. taurica, is a destructive problem in pepper and tomato $(15,40)$. Part of the L. taurica life cycle takes place inside the leaf, whereas other powdery mildew fungi grow only on the leaf surface. Most of the visible symptoms can be found on the lower leaf surface, either because of the higher density of stomata on this side or because the microclimate there is more suitable for disease development, but typical symptoms may sometimes appear on the upper side of the leaf as well (40). Light yellow spots occur on the upper surface while white colonies grow on the lower surface. Powdery mildew colonies may coalesce during severe epidemics (40). A major problem in this pathosystem is the fact that pepper leaves are shed when they are infected by powdery mildew, meaning that the lost photosynthetic area is greater than the area covered by powdery mildew colonies (15). As a result of leaf shedding, fruit are exposed to sun burn damage (40). In tomato plants, infected leaves die intact. The management of $L$. taurica powdery mildew relies mainly on fungicides, among which sulfur is an important control agent (15). Heat treatment was suggested for the control of this disease and it was suggested that at least part of its activity stems from induced resistance mode of action (15). L. taurica powdery mildew can be suppressed by systemic induced resistance (46).

B. cinerea (gray mold) infects many vegetable, ornamental, and horticultural crops (16), including several greenhouse crops $(18,16)$. Plant physiology, as affected by plant nutrition, can also affect susceptibility to $B$. cinerea infection $(17,23,60)$. In some cases, calcium ( $\mathrm{Ca}$ ) fertilization and the presence of high concentrations of $\mathrm{Ca}$ in the plant tissues have been shown to effectively reduce gray mold severity $(23,60,67)$. ISR was found to be effective in suppression of gray mold in several crops (12).

The broad mite (Polyphagotarsonemus latus Banks; order: Acari, family: Tarsonemidae) has a large host range, including 60 families of plants. Its vegetable hosts include beet, bean, cucumber, eggplant, pepper, potato, and tomato. Damage is especially severe in bell pepper. The damage is caused by secretion of a plant growth regulator or toxin as the mite feeds, and significant damage can occur at very low pest density. Symptoms include leaf and fruit distortions, shortening of internodes, blistering, shriveling and curling of leaves, and leaf discoloration. Fruit may be deformed, split, or russeted. Infestations in pepper can cause a bronzing of terminal growth and are frequently associated with a characteristic S-shaped twisting of the main stem in leaves. Some acaricides provide excellent control, and biocontrol is developed for this mite (64).

\section{MATERIALS AND METHODS}

Plants and biochar. Biochar prepared from citrus wood in a traditional charcoal kiln (lump charcoal) was obtained. The biochar contained $70.6 \% \mathrm{C}, 0.6 \% \mathrm{~N}, 2.3 \% \mathrm{H}$, and $26.4 \% \mathrm{O}$, and the only mineral phases identified by X-ray diffraction in the biochar were quartz and calcite, at relatively low levels (unpublished data). The biochar was ground into a powder of less than $0.5-\mathrm{mm}$ particles and stored in a sealed sterile metal box until use. The biochar powder was mixed with either an organic matter (OM)-poor sandy soil (Besor region, western Negev, Israel; $0.4 \%$ OM, $92 \%$ sand, $1.5 \%$ silt, and $6.5 \%$ clay) or a coconut fiber-tuff (unsorted to $8 \mathrm{~mm})(7: 3, \mathrm{vol} / \mathrm{vol})$ potting mixture. Plants of tomato (Lycopersicum esculentum) cv. 1402 (Hazera Genetics, Ltd., Brurim M.P. Shikmim, Israel) and sweet pepper (Capsicum annuum) cv. Maccabi (Hazera Genetics, Ltd.) were obtained from a commercial nursery (Hishtil, Ashkelon, Israel) at 40 to 50 days after seeding and transplanted into 1-liter pots containing the soil or potting medium without or with biochar at 1,3 , or $5 \%$ by weight. Plants were fertigated proportionally with drippers two to three times per day with 5:3:8 NPK fertilizer (irrigation water was planned to have total $\mathrm{N}, \mathrm{P}$, and $\mathrm{K}$ concentrations of 120,30 , and $150 \mathrm{mg} / \mathrm{liter}$, respectively; EC $2.2 \mathrm{dS} / \mathrm{m}$ ), allowing for 25 to $50 \%$ drainage. Plants were maintained at 20 to $30^{\circ} \mathrm{C}$ in a pest- and disease-free greenhouse for 1 to 2 months and then transferred to an area where diseases were allowed to develop following inoculation of intact or detached leaves as described below.

Gray mold inoculation and evaluation. $B$. cinerea (isolate BcI16) (53) was cultured on potato dextrose agar (PDA) (Difco Laboratories, Detroit) in petri dishes incubated at $20^{\circ} \mathrm{C}$. Conidia were harvested from 10- to 14-day-old cultures by agitating $1 \mathrm{~cm}^{2}$ of agar bearing mycelium and conidia in a glass tube with tap water. The suspension was then filtered through cheesecloth. The concentration of conidia was determined using a hemacytometer and a light microscope, and adjusted to $5 \times 10^{5}$ cells $/ \mathrm{ml}$. Because $B$. cinerea conidia need carbon and phosphate for germination and penetration (9), $0.1 \%$ glucose was added to the final conidial suspension together with $0.1 \% \mathrm{KH}_{2} \mathrm{PO}_{4}$. These supplements have been shown to facilitate germination of $B$. cinerea conidia and subsequent leaf infection (14).

Attached tomato leaves were examined. Whole plants were kept in a humidity chamber at $20 \pm 1^{\circ} \mathrm{C}, 97 \pm 3 \%$ relative humidity, and 1,020 lux light intensity. Five leaves/plant from at least five plants were each inoculated with a $10-\mu$ drop of a $5 \times$ $10^{5}$ conidia/ml suspension. The severity of the resulting necrotic lesion on each leaf was determined according to the scale described below (20). The diameter of a 10- $\mu$ l drop of inoculum 
on a leaf was $\approx 3 \mathrm{~mm}$, which corresponded to an area of $7 \mathrm{~mm}^{2}$. Disease developed gradually and was first visible at 3 to 5 days after inoculation. Initially, each infection was observed as a small necrotic lesion covering only part of the area originally covered by the drop of $B$. cinerea conidial suspension. The diameter of a $B$. cinerea lesion on a typical tomato leaf 9 to 10 days after inoculation was $\approx 9 \mathrm{~mm}$, which corresponded to an area of $63.5 \mathrm{~mm}^{2}$. A 12-mm-diameter lesion (corresponding to an area of $113 \mathrm{~mm}^{2}$ ) was used as a base size and assigned a value of $100 \%$, because this was the maximum lesion size observed. A pictorial scale of lesion sizes was used for evaluating the observed disease, including the following relative sizes: $0,1,2,5,10,20,40,75$, and $100 \%$ of a $113-\mathrm{mm}^{2}$ lesion. Lesion size (a measure of disease severity) was determined for each lesion using this pictorial scale (20). Alternatively, detached pepper leaves were inoculated with 3-mm-diameter mycelium agar discs of 4-day-old B. cinerea cultures, and the diameter of the developing rot was measured and its area calculated.

Powdery mildew inoculation and evaluation. L. taurica was isolated from young leaves of sweet pepper plants grown in a commercial greenhouse at the Besor Research and Development station, western Negev, Israel. Conidia of the pathogen were collected by rinsing infected leaves with sterile water and were counted under a light microscope using a hemacytometer. For the artificial infection of pepper leaves, the concentrations of these conidia suspensions were adjusted to $10^{5} / \mathrm{ml}$ and the suspensions were sprayed onto plants at a volume of $2 \mathrm{ml} /$ plant within 10 to $15 \mathrm{~min}$ of the initial conidia collection. Disease severity was evaluated several times after infection. There were 5 to 10 plants in each treatment. Leaves at three plant heights were evaluated for the determination of percent coverage with powdery mildew symptoms. The severity (percentage) of leaf coverage in each plant was calculated by averaging the severity values at different plant heights. One leaf was sampled at each plant height over the sampled plants in each treatment (15).

Broad mite inoculation and evaluation. The broad mite $(P$. latus) infestation was natural on the pepper plants placed in the greenhouse at 20 to $30^{\circ} \mathrm{C}$. Symptoms of leaf distortions, shortening of internodes, blistering, and shriveling and curling of leaves were evaluated on a 0 to $100 \%$ scale where $0=$ completely normal-looking plant and $100=$ fully damaged plant.

Experimental design and statistical analysis. Treatments in experiments were replicated 5 to 10 times. Replicates of each treatment were arranged randomly. Disease severity (leaf coverage) was averaged per leaf level (node), plant, and replicate, and area under the disease progress curves (AUDPC) values were calculated. Data in percentages were arcsin-transformed before further analysis. Disease severity and AUDPC data were analyzed using analysis of variance and Fisher's protected least significant difference test. Standard errors (SEs) of the means were calculated and disease levels were statistically separated following a one-way analysis of variance. Statistical analysis was done using the R version 2.10.1 software (http://www.r-project.org). Experiments were carried out three to four separate times; exemplary results are presented below. In the long-term experiment, a logit calculation was used to describe the epidemic rate, using the formula $(\ln [x /(100-x)]$ where $x=$ disease severity value (in the range of 0.5 to $99.5 \%$ ).

\section{RESULTS}

Effect of biochar, plant growth substrate, and leaf height on pepper powdery mildew. The effect of biochar presence in the root zone on plant susceptibility to foliar pathogens was first tested with the biotroph pathogen $L$. taurica. Pepper plants grown in biochar-amended soil and potting medium had a significantly lower severity of powdery mildew. This is shown for lower leaves of pepper plants grown in both soil and potting medium 31 days following infection (Fig. 1A). Interestingly, the coconut fiber-tuff soilless potting medium was found to be more conducive to disease development than the soil (Fig. 1A). Powdery mildew reduction was observed on leaves at three heights on pepper plants grown in biochar-amended soil (Fig. 1B), with a significant difference $(P=0.002)$ in the calculated whole-plant disease severity values for control plants and $5 \%$ biochar-amended plants of $11.8 \pm 1.4$ (average \pm SE) and $4.2 \pm 0.3 \%$, respectively, 31 days following infection.

Effect of biochar on gray mold. Leaves of tomato and pepper plants grown in potting medium amended with $5 \%$ biochar or in the nonamended potting medium were infected by $B$. cinerea 52 days after planting in order to test whether the effect of biochar is also extended to a necrotrophic pathogen. Gray mold on mycelium-infected detached pepper leaves from the biocharamended medium was significantly reduced by $58 \%$ (calculated from AUDPC values, $P=9 \times 10^{-7}$ ) (Fig. 2). Gray mold on conidia-infected tomato leaves attached to the whole plants grown in biochar-amended medium was also significantly reduced by $75 \%$ compared with the nonamended control (calculated from AUDPC values, $P=0.05$ ) (Fig. 3).

Effect of biochar concentration. Biochar applied to the potting medium at concentrations of 3 and $5 \%$ was effective in inducing the suppression of pepper powdery mildew at all leaf heights and throughout the 60-day sampling interval following infection (Fig. 4). AUDPC of disease severity at the different plant heights was also significantly reduced by each of the biochar-tested concentrations ( $P=0.00002$ to 0.0007$)$. There were no significant differences between the biochar concentrations as demonstrated in the calculated whole-plant disease severity calculations (Table 1) or its AUDPC of whole-plant severity that reached values of (average \pm SE) $1,017 \pm 126,299 \pm 88$, and $199 \pm 25 \% \times$ days in the untreated control, 3 and $5 \%$ biochar treatments, respectively.

In addition, the biochar induced the suppression of symptoms caused by the broad mite on the pepper canopy, with no significant difference between the two biochar levels (3 and 5\%) $(P=0.003)$ (Fig. 5). Similarly, the AUDPC of gray mold severity in leaves of whole tomato plants was significantly reduced by 3
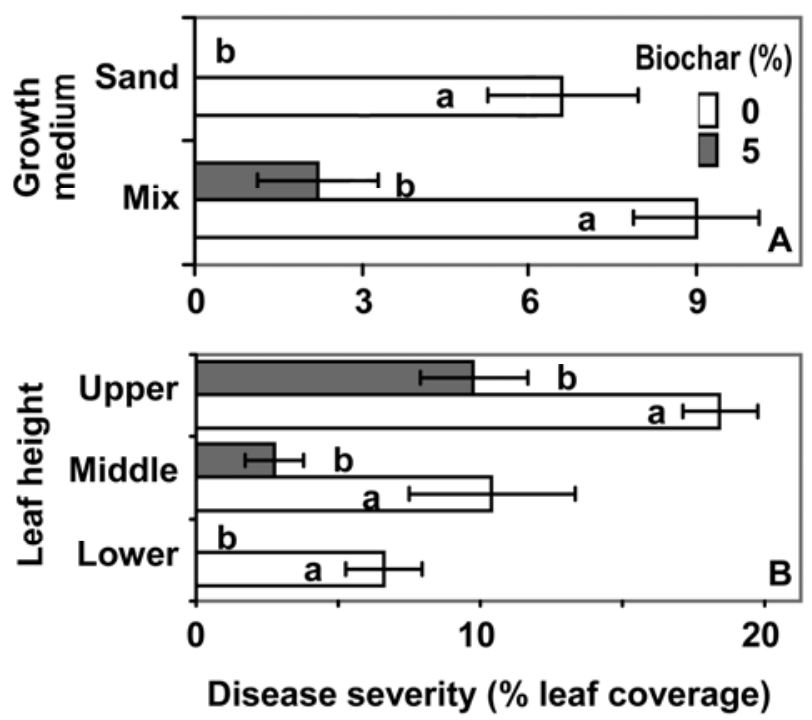

Fig. 1. Effect of biochar on development of powdery mildew (Leveillula taurica) on $\mathbf{A}$, lower leaves of pepper plants grown in soil or potting medium and $\mathbf{B}$, leaves at three different heights of pepper plants grown in soil. Evaluation was carried out 31 days after infection and disease severity is expressed as percentage of leaf coverage. Plants were grown at 20 to $30^{\circ} \mathrm{C}$. Bars represent the standard error of the mean of six replicates. Data points labeled by a common letter are not significantly different according to Fisher's protected least significant difference test. 
and $5 \%$ biochar $(P=0.0013)$, with no significant difference between the two levels; however, at 6 days after infection, severity of the disease was significantly lower at $5 \%$ biochar than at $3 \%$ biochar (Fig. 6).

Effect of leaf age and exposure duration on induced resistance by biochar. Leaves of pepper plants planted in potting medium with 0,1 , and $3 \%$ biochar were sampled 50 and 94 days after planting for $B$. cinerea challenge. Young leaves were less susceptible to gray mold development than older leaves; nevertheless, the induction by biochar at both concentrations resulted in complete suppression of grey mold (Fig. 7A and B). There was still a significant suppressive effect of the biochar treatment on disease progression 44 days later (compare Fig. 7C to B).

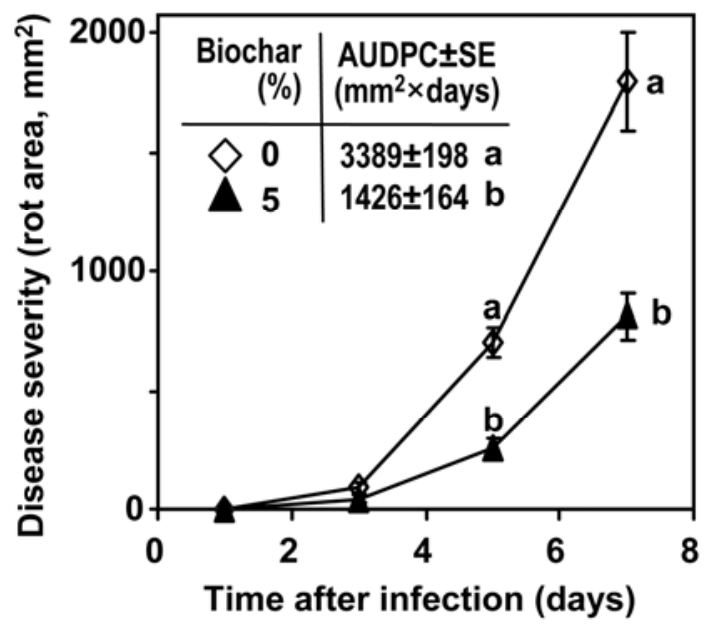

Fig. 2. Effect of biochar mixed in soil on development of gray mold (Botrytis cinerea) on leaves detached from treated pepper plants 52 days after planting. Disease is presented as rot area following infection by mycelium disks and as area under the disease progress curve \pm standard error (AUDPC \pm SE) through 7 days. Plant material was incubated at $20 \pm 1^{\circ} \mathrm{C}, 97 \pm 3 \%$ relative humidity, and 1,020 lux light intensity. Bars represent the standard error of the mean of eight replicates. At a given sampling date data points labeled by a common letter are not significantly different according to Fisher's protected least significant difference test.

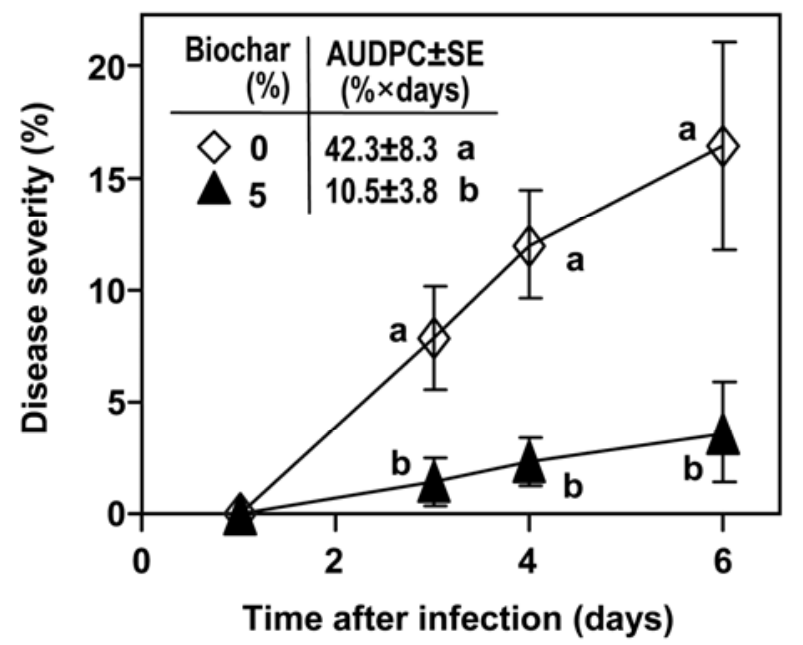

Fig. 3. Effect of biochar mixed in potting medium on development of gray mold (Botrytis cinerea) on attached leaves of tomato plants 21 days after planting. Disease is presented as percentage of maximal severity values following inoculation with drops of conidia suspension and as area under the disease progress curve \pm standard error (AUDPC \pm SE) through 6 days. Plants were incubated at $20 \pm 1{ }^{\circ} \mathrm{C}, 97 \pm 3 \%$ relative humidity, and 1,020 lux light intensity. Bars represent the standard error of the mean of eight replicates. At a given sampling date data points labeled by a common letter are not significantly different according to Fisher's protected least significant difference test.
Tomato powdery mildew was evaluated four times during a period of 30 to 59 days after infection with L. taurica. Severity of disease in the control plants reached 75 to $100 \%$ leaf coverage in the older leaves (Fig. 8B and C) and $18 \%$ on younger leaves $(P \leq$ $0.05)$. Biochar applied to the potting medium at concentrations of 1 and $3 \%$ significantly suppressed the severity of disease in both young and old leaves (Fig. 8). The calculated whole-plant disease severity was significantly reduced by both biochar concentrations at all four sampling dates and as calculated for the entire sampling period, as shown for the AUDPC (Table 2).

Long-term effect of biochar on disease resistance. The severity of pepper powdery mildew was significantly lower on plants treated by 1 and $3 \%$ biochar than on untreated control
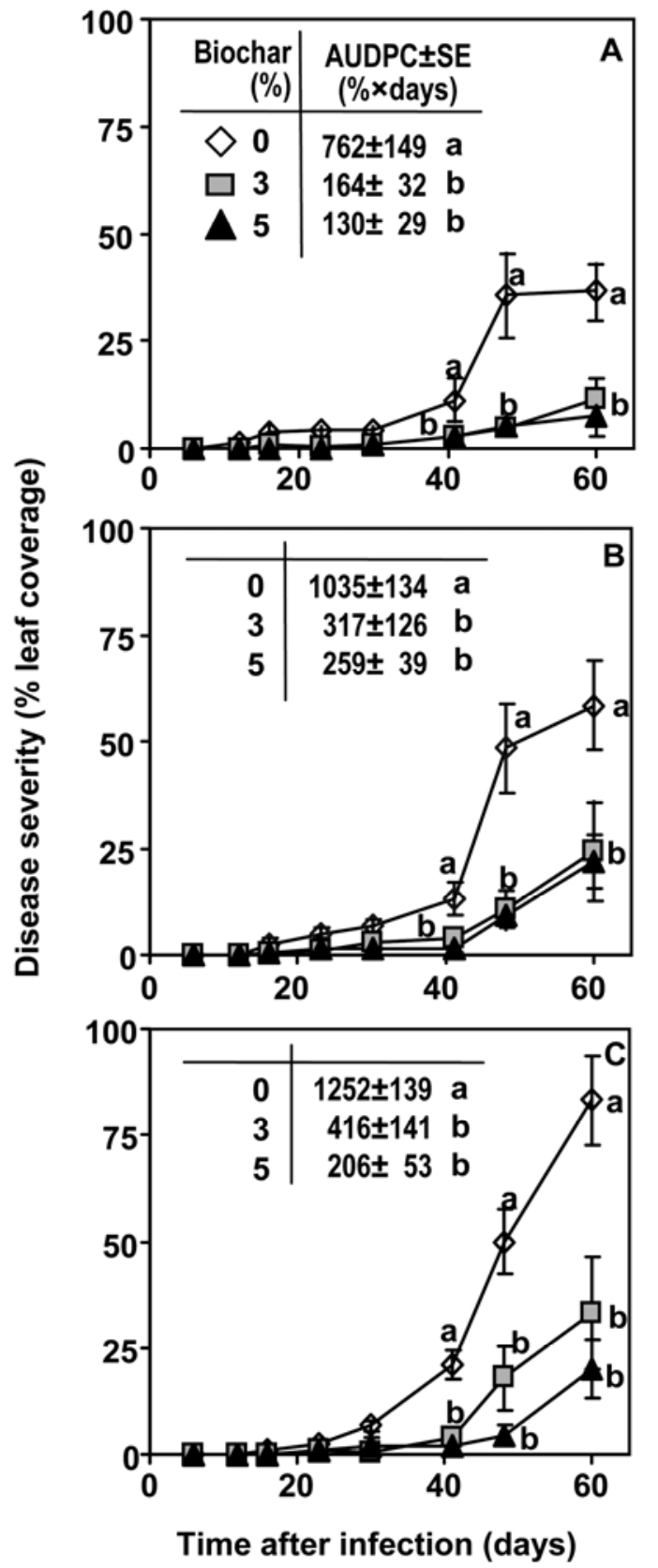

Fig. 4. Effect of biochar in potting medium on powdery mildew (Leveillula taurica) on pepper plants inoculated 35 days after planting and evaluated on $\mathbf{A}$, upper; $\mathbf{B}$, middle; and $\mathbf{C}$, lower leaves. Disease is presented as percentage of leaf coverage and as area under the disease progress curve \pm standard error (AUDPC \pm SE) through 60 days. Plants were incubated under conditions of 20 to $30^{\circ} \mathrm{C}$. Bars represent the standard error of the mean of six replicates. At a given sampling date data points labeled by a common letter are not significantly different according to Fisher's protected least significant difference test. 
plants throughout a period of 105 days (Fig. 9). Disease at all three leaf height levels was significantly reduced by both biochar treatments throughout the full period of observation (results not shown). Calculated whole-plant disease severity was also reduced by both biochar treatments throughout the full period of observation (Table 3 ). The reduction in whole-plant severity was due to the delay in the development of the epidemic in the biochar treatments compared with the untreated control (Fig. 9; Table 4) rather than a reduction in the rate of disease progression, which was similar in all the treatments (Table 4). It is possible to calculate from the linear regression of the logit transformation that the delay period was 20 days.

\section{DISCUSSION}

In the present research, mixing biochar in the soil and potting medium resulted in reduction of damage caused by necrotrophic (B. cinerea) and biotrophic (L. taurica) foliar pathogens on two crops (pepper and tomato) and by one mite pest ( $P$. latus) on pepper plants. The fact that the biochar location during all stages of plant development was spatially separated from the site of infection is strongly suggestive that there was no direct toxicity toward the causal agents, and that the phenomenon we observed is systemic induced resistance in the form of either ISR or SAR. Systemic resistance induced by biochar in the present study was significantly effective at biochar concentrations of 1 to $5 \%$ in both crops, both plant diseases, and across leaves located at the three plant levels and representing different tissue ages. In most instances, there was no significant difference in biochar effectiveness at different application levels (Figs. 4 and 5, 3 versus 5\%; or Figs. 7 to 9, 1 versus $3 \%$ ). However, one system (B. cinerea on attached leaves of tomato plants grown in potting medium) (Fig. 6) did display significantly superior disease suppression at $5 \%$ compared with $3 \%$ biochar. There is no standard recommended application rate for biochar; however, the levels used in this research are similar to those commonly reported in the literature $(7,19,33,51)$. Clearly, more research must be done to quantify the extent to which biochar elicits systemic plant defenses, and in which plant-biochar-porous medium systems.

It is well known that the medium in which a plant is grown can affect disease incidence. For example, compost has frequently been reported to have a disease-suppressive effect on soilborne diseases $(34,39)$. Many mechanisms have been suggested to account for compost disease suppressive effects on soil pathogens, including competition for nutrients, antibiosis, and predation of pathogens by the compost-indigenous microbial consortium, increase in soil nutrient levels, and induced resistance via abiotic or biotic elicitors $(24,29,37)$. By way of contrast, biochar is initially sterile, being prepared by thermal anaerobic decomposition of biomass at temperatures exceeding $350^{\circ} \mathrm{C}$. Therefore, there is no biochar-borne population of microorganisms to potentiate disease suppression.

Although biochar does not have an indigenous consortium of microorganisms, there are a number of potential ways in which biochar amendments may induce systemic plant defenses against disease: improved nutrient supply, stimulation of a beneficial soil microbial consortium, input of chemical elicitors such as salts and organic chemicals, or improvement in soil physical qualities. The possibility that these factors were responsible for the observed induced resistance is considered below.

Concentrations of nutritional elements in tomato and pepper leaves were within the optimal range for tomato and pepper plants $(1,49)$ and, importantly, there were no significant differ-

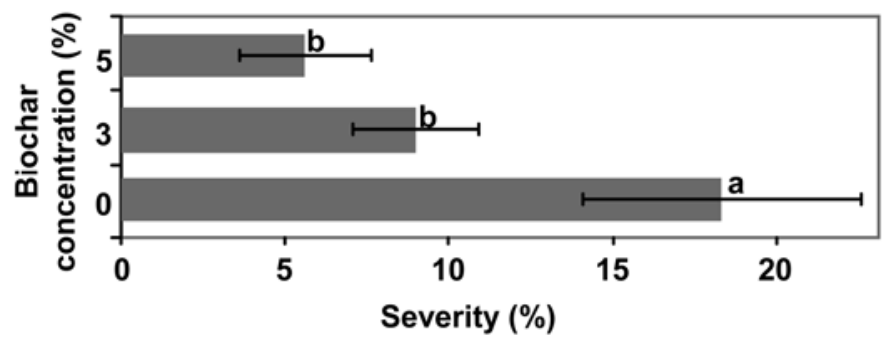

Fig. 5. Effect of biochar in potting medium on symptoms of broad mite (Polyphagotarsonemus latus) on pepper plants 57 days after planting. Severity is presented as percentage of plant damaged. Bars represent the standard error of each mean. Plants were incubated at $20 \pm 1{ }^{\circ} \mathrm{C}, 97 \pm 3 \%$ relative humidity, and 1,020 lux light intensity. Each mean is an average of five replicates. Treatments followed by a common letter are not significantly different according to Fisher's protected least significant difference test.

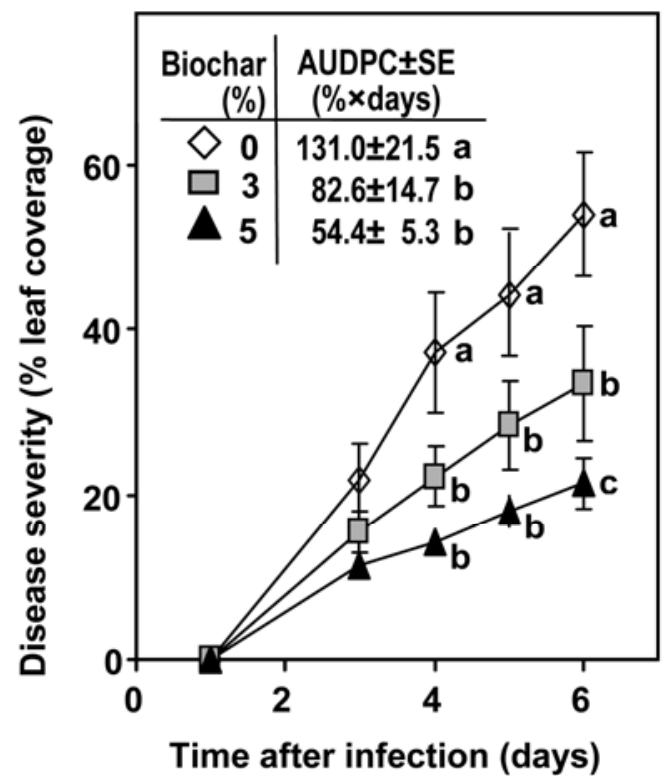

Fig. 6. Effect of biochar in potting medium on development of gray mold (Botrytis cinerea) on attached leaves of tomato plants 21 days after planting. Disease is presented as percentage of maximal severity values following inoculation with drops of conidia suspension and as area under the disease progress curve \pm standard error (AUDPC \pm SE) through 6 days. Plants were incubated at $20 \pm 1{ }^{\circ} \mathrm{C}, 97 \pm 3 \%$ relative humidity, and 1,020 lux light intensity. Bars represent the standard error of the mean of six replicates. At a given sampling date data points labeled by a common letter are not significantly different according to Fisher's protected least significant difference test.

TABLE 1. Effect of biochar concentrations (Conc.) on whole pepper plant powdery mildew (Leveillula taurica) severity

\begin{tabular}{|c|c|c|c|c|c|c|c|}
\hline \multirow[b]{2}{*}{ Conc. $(\%)$} & \multicolumn{7}{|c|}{ Time after infection (days) } \\
\hline & 12 & 16 & 23 & 30 & 41 & 48 & 60 \\
\hline 0 & $0.8 \pm 0.3 \mathrm{a}^{\mathrm{z}}$ & $2.1 \pm 0.5 \mathrm{a}$ & $3.9 \pm 0.5 \mathrm{a}$ & $5.9 \pm 0.8 \mathrm{a}$ & $15.2 \pm 3.3 \mathrm{a}$ & $44.7 \pm 7.5 \mathrm{a}$ & $59.4 \pm 7.1 \mathrm{a}$ \\
\hline 3 & $0.1 \pm 0.1 \mathrm{~b}$ & $0.4 \pm 0.3 b$ & $0.9 \pm 0.5 b$ & $2.2 \pm 0.7 b$ & $2.9 \pm 0.5 b$ & $11.1 \pm 3.9 b$ & $23.1 \pm 7.4 b$ \\
\hline 5 & $0.1 \pm 0.1 \mathrm{~b}$ & $0.2 \pm 0.2 b$ & $1.3 \pm 0.6 b$ & $1.1 \pm 0.5 \mathrm{~b}$ & $2.1 \pm 1.2 \mathrm{~b}$ & $6.3 \pm 1.2 b$ & $16.5 \pm 4.3 b$ \\
\hline$P=$ & 0.008 & 0.008 & 0.006 & 0.007 & 0.00002 & 0.00002 & 0.0005 \\
\hline
\end{tabular}

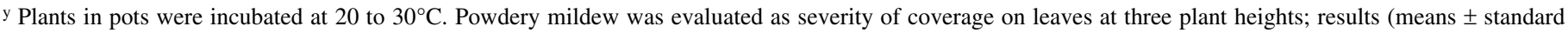
error) are presented as percent leaf coverage at each sampling date.

z Treatments in each column followed by the same letter are not significantly different according to Fisher's protected least significant difference test. 
ences between the various treatments and controls (unpublished data). As such, nutrient supplementation in the biochar-amended treatments could not explain the observed systemic induced resistance.

Biochar has been reported to affect some soil physical properties, including increased soil water retention (26). In the experiments, water was supplied in two to three doses daily and in excess of plant need between 25 to $50 \%$. Accordingly, we do not expect that water stress had a role in the observed induced resistance. Nor is it anticipated that osmotic or $\mathrm{pH}$ stresses had any function in the observed induced resistance, because the EC of a $10 \%$ biochar/water extract was only $1.6 \mathrm{dS} / \mathrm{m}$ (compared with the EC of the fertigation solution of $2.2 \mathrm{dS} / \mathrm{m}$ ), and $\mathrm{pH}$ was 7.6 (unpublished data).

Biochars contain residual tars which comprise a complex mixture of dozens of individual organic compounds $(47,48)$. In general, some compounds found in the tar fraction of chars have been found to aid in seed germination, others to trigger the growth of microorganisms, and yet others to have biocidal properties (3). In the biochar used in the present work, compounds in the residual tars represented a number of major chemical classes, including medium- and long-chain $n$-alkanoic acids, hydroxy and acetoxy acids, benzoic acids, short- and mediumchain diols and triols, phenols and polyphenols, and aliphatic hydrocarbons (unpublished data). A number of the identified compounds are known to exhibit phytotoxic and biocidal activities; for example, ethylene and propylene glycol, hydroxypropionic and butyric acids, benzoic acid and o-cresol, quinones (1,3-dihyroxybenzene and 1,4-dihydroxybenzene), and phenoxyethanol. These compounds are present in the biochar at relatively low levels. It may be hypothesized that plants in the biocharamended soils responded to the stress of low levels of phytotoxic compounds in the root zone via an induced resistance mechanism such as reported for Arabidopsis thaliana in the presence of low levels of ( \pm )-catechin (43). In that study, A. thaliana exhibited an inverted U-shaped growth response to $( \pm)$-catechin, which is phytotoxic at high concentrations. At low concentrations where growth was promoted, plant leaves inoculated with Pseudomonas syringae pv. tomato, a pathogen of A. thaliana, developed restricted lesions only at the site of inoculation, whereas the control plants exhibited widespread infection, indicating the development of systemic induced resistance in the face of low levels of phytotoxic compounds (43).

We found that culturable populations of bacteria, actinomycetes, yeasts, filamentous fungi (including Trichoderma spp.) were augmented in the biochar-amended soil and potting medium (unpublished data). A number of species belonging to the augmented groups are known to potentiate plant systemic resistance in many systems $(22,27)$. For example, Trichoderma harzianummediated ISR was shown to reduce gray mold symptoms in Arabidopsis (28); tomato, pepper, and bean plants (12); and grape (41). The shifts in microbial populations may have been stimulated by the low levels of biocidal agents present in the biochar. Alternatively, the porous structure of the biochar may have provided physical refuge for various beneficial microorganisms.

In conclusion, in this pioneering study, we found that additions of biochar (1, 3, and $5 \%$ by weight) to a typical potting mixture and to a sandy soil successfully induced resistance against two foliar fungal pathogens (B. cinerea and L. taurica) in both pepper and tomato plants, and to a pest (Polyphagotarsonemus latus) in pepper plants. Given that the biochar was soil applied and a suppressive effect was found for foliar pathogens and a foliar pest, it is clear that the biochar was able to induce a systemic response. The induced response may have been promoted by biotic agents, as a result of stress derived from the presence of low levels of phytotoxic compounds, or through the action of chemical elicitors. Improved plant nutrition and water balance can be eliminated as factors in the suppressive effect. Future research (already underway) is focusing on characterizing the involved

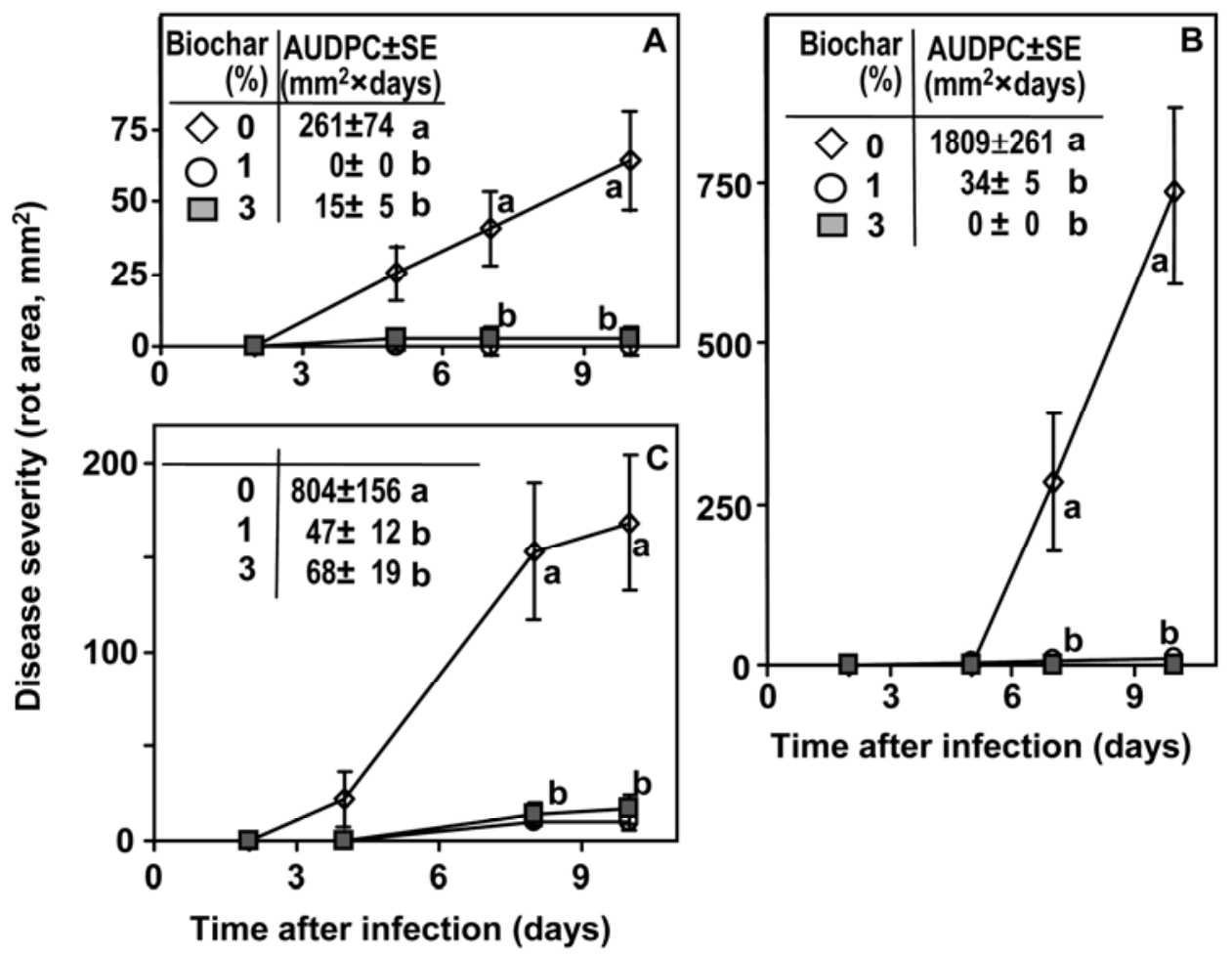

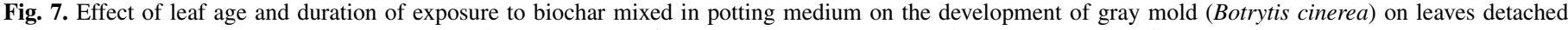

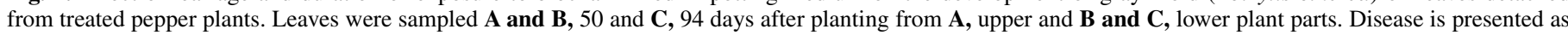

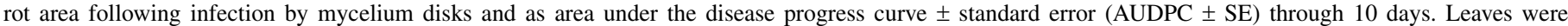

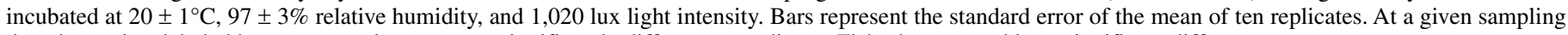
date data points labeled by a common letter are not significantly different according to Fisher's protected least significant difference test. 
elicitors and in deciphering the induced resistance pathways, as well as on examining the impact of biochar on plant priming against abiotic stresses. Improved plant resistance to biotic stresses is yet an additional benefit to be had from biochar application in soil, together with improved crop production, soil water retention, and soil tilth. The development of agricultural markets

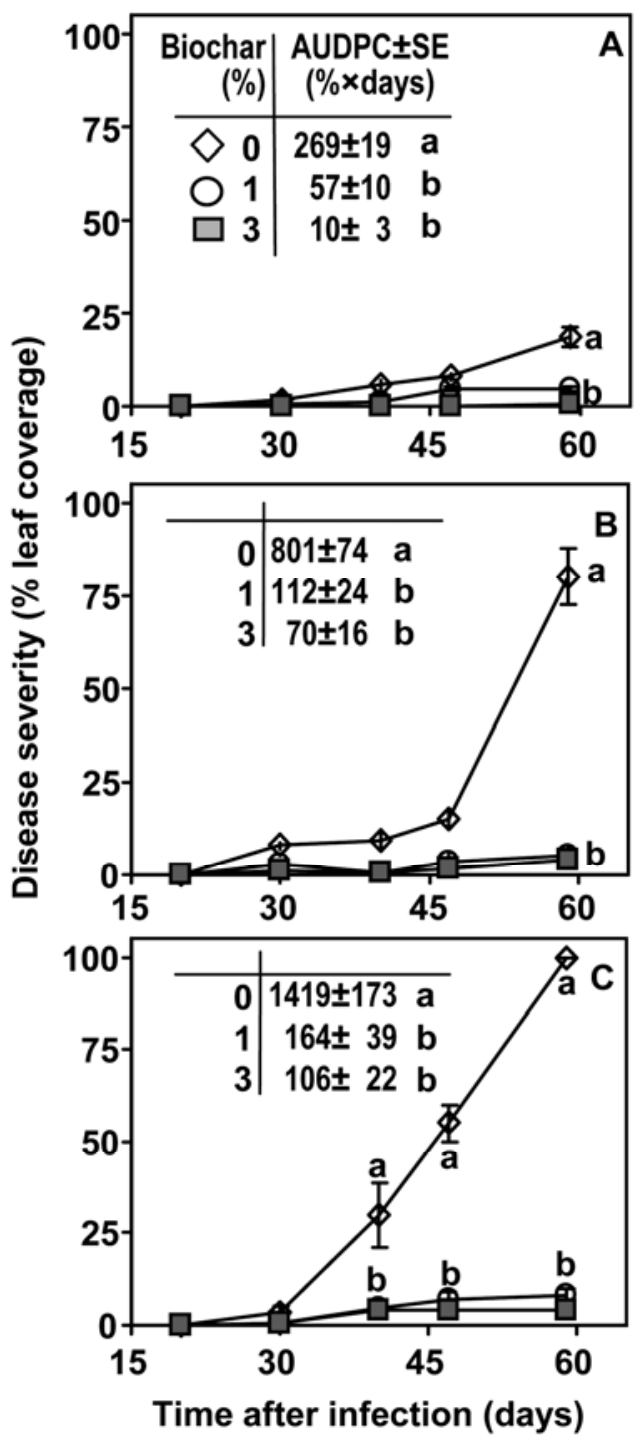

Fig. 8. Effect of biochar mixed in potting medium on powdery mildew (Leveillula taurica) on tomato plants inoculated 60 days after planting and evaluated on A, upper; $\mathbf{B}$, middle; and $\mathbf{C}$, lower leaves. Disease is presented as percentage of leaf coverage and as area under the disease progress curve \pm standard error (AUDPC \pm SE) through 59 days. Plants were incubated under conditions of 20 to $30^{\circ} \mathrm{C}$. Bars represent the standard error of the mean of six replicates. At a given sampling date data points labeled by a common letter are not significantly different according to Fisher's protected least significant difference test.

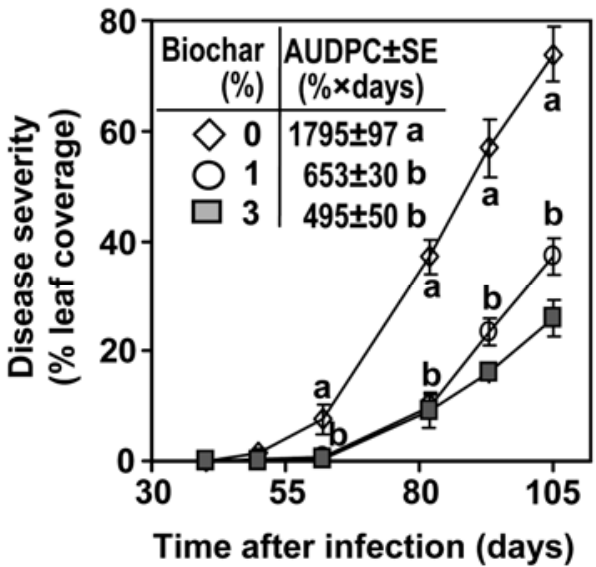

Fig. 9. Long-term effect of biochar mixed in potting medium on powdery mildew (Leveillula taurica) on tomato plants inoculated 50 days after planting and evaluated on leaves at three plant heights. Disease is presented as percentage of leaf coverage on a whole plant average and as area under the disease progress curve \pm standard error (AUDPC \pm SE) through 105 days. Plants were incubated under conditions of 20 to $30^{\circ} \mathrm{C}$. Bars represent the standard error of the mean of six replicates. At a given sampling date data points labeled by a common letter are not significantly different according to Fisher's protected least significant difference test.

TABLE 3. Effect of biochar concentration (Conc.) on severity of powdery mildew (Leveillula taurica) on three levels of leaves of pepper plants grown in a long-term experiment ${ }^{\mathrm{y}}$

\begin{tabular}{lccc}
\hline & \multicolumn{3}{c}{ Leaf level $^{\mathrm{z}}$} \\
\cline { 2 - 4 } Conc. (\%) & Lower & Middle & Upper \\
\hline 0 & $2,063 \pm 157 \mathrm{a}$ & $1,679 \pm 128 \mathrm{a}$ & $1,643 \pm 104 \mathrm{a}$ \\
1 & $585 \pm 57 \mathrm{~b}$ & $536 \pm 64 \mathrm{~b}$ & $841 \pm 57 \mathrm{~b}$ \\
3 & $443 \pm 108 \mathrm{~b}$ & $469 \pm 32 \mathrm{~b}$ & $573 \pm 104 \mathrm{~b}$ \\
$P=$ & $5 \times 10^{-9}$ & $4 \times 10^{-9}$ & $1 \times 10^{-7}$ \\
\hline
\end{tabular}

${ }^{\mathrm{y}}$ Severity of powdery mildew was evaluated as percentage of leaf coverage; results (means \pm standard error) are presented as areas under disease progress curves (AUDPC; $\% \times$ days) through 105 days after infection. Plants in pots were incubated at 20 to $30^{\circ} \mathrm{C}$.

${ }^{\mathrm{z}}$ Treatments in each column followed by the same letter are not significantly different according to Fisher's protected least significant difference test.

TABLE 4. Rate of disease development of epidemics of pepper powdery mildew (Leveillula taurica) as affected by biochar soil treatments ${ }^{\mathrm{x}}$

\begin{tabular}{lccc}
\hline $\begin{array}{l}\text { Biochar } \\
\text { concentration } \\
(\%)\end{array}$ & $\begin{array}{c}\text { Rate of change } \\
\text { in disease severity } \\
\text { (logit) }( \pm \text { error })^{\mathrm{y}, \mathrm{z}}\end{array}$ & $\begin{array}{c}\text { Intercept } \\
( \pm \text { error })^{\mathrm{z}}\end{array}$ & $R^{2}$ \\
\hline 0 & $0.096 \pm 0.082$ & $-8.700 \pm 0.664$ & 0.989 \\
1 & $0.109 \pm 0.009$ & $-11.604 \pm 0.759$ & 0.989 \\
3 & $0.100 \pm 0.019$ & $-11.086 \pm 1.647$ & 0.966 \\
\hline
\end{tabular}

${ }^{\mathrm{x}}$ Disease severity values are based on epidemics that developed during 105 days after infection.

${ }^{y}$ Logit values $(\ln [x /(100-x)])$ were calculated for the disease severity values following disease inoculation. The change was calculated according to the slope and intercept of the best fit linear regression line for time (x-axis) versus disease severity logit values (y-axis).

${ }^{\mathrm{z}}$ Error of estimated parameters of best-fit linear regression line.

TABLE 2. Effect of biochar concentrations (Conc.) on severity of powdery mildew (Leveillula taurica) on leaves of tomato plants ${ }^{y}$

\begin{tabular}{|c|c|c|c|c|c|}
\hline \multirow[b]{2}{*}{ Conc. $(\%)$} & \multicolumn{4}{|c|}{ Time after infection (days) } & \multirow[b]{2}{*}{ AUDPC } \\
\hline & 30 & 40 & 47 & 59 & \\
\hline 0 & $5.6 \pm 0.7 \mathrm{a}^{\mathrm{z}}$ & $13.8 \pm 2.8 \mathrm{a}$ & $25.9 \pm 5.1 \mathrm{a}$ & $66.1 \pm 4.3 \mathrm{a}$ & $829.7 \pm 61.2 \mathrm{a}$ \\
\hline 1 & $1.3 \pm 0.4 \mathrm{~b}$ & $3.4 \pm 1.4 \mathrm{~b}$ & $4.4 \pm 1.1 \mathrm{~b}$ & $3.9 \pm 1.1 \mathrm{~b}$ & $111.0 \pm 29.1 \mathrm{~b}$ \\
\hline$P=$ & $1 \times 10^{-6}$ & $9 \times 10^{-5}$ & $2 \times 10^{-5}$ & $6 \times 10^{-12}$ & $1 \times 10^{-7}$ \\
\hline
\end{tabular}

y Powdery mildew was evaluated as severity of leaf coverage; results (means \pm standard error) are presented as percent leaf coverage at each sampling date and as areas under disease progress curves (AUDPC; $\% \times$ days) through 59 days after infection. Plants in pots were incubated at 20 to $30^{\circ} \mathrm{C}$.

${ }^{\mathrm{z}}$ Treatments in each column followed by the same letter are not significantly different according to Fisher's protected least significant difference test. 
for biochar products, including as a disease control agent, can help promote the adoption of biomass pyrolysis as an important tool in both mitigation of, and adaptation to, climate change.

\section{ACKNOWLEDGMENTS}

The research was funded by Autonomous Province of Trento, Call for Proposal Major Projects 2006, Project ENVIROCHANGE. We thank R. Shulhani for help in establishing experiments and treating plants.

\section{LITERATURE CITED}

1. Adams, P. 2002. Nutritional control in hydroponics. Pages 211-262 in: Hydroponic Production of Vegetables and Ornamentals. D. Savvas and H. Passam, eds. Embryo Publications, Athens.

2. Ahn, I. P., Lee, S. W., and Suh, S. C. 2007. Rhizobacteria-induced priming in Arabidopsis is dependent on ethylene, jasmonic acid, and NPR1. Mol. Plant-Microbe Interact. 20:759-768.

3. Amonette, J. E., and Joseph, S. 2009. Characteristics of biochar: microchemical properties. Pages 33-52 in: Biochar for Environmental Management. J. Lehmann and S. Joseph, eds. Earthscan, London.

4. Ayres, P. G. 1984. The interaction between environmental-stress injury and biotic disease physiology. Annu. Rev. Phytopathol. 22:53-75.

5. Aziz, A., Trotel-Aziz, P., Dhuicq, L., Jeandet, P., Couderchet, M., and Vernet, G. 2006. Chitosan oligomers and copper sulfate induce grapevine defense reactions and resistance to gray mold and downy mildew. Phytopathology 96:1188-1194.

6. Belhadj, A., Saigne, C., Telef, N., Cluzet, S., Bouscaut, J., Corio-Costet, M. F., and Mérillon, J. M. 2006. Methyl jasmonate induces defense responses in grapevine and triggers protection against Erysiphe necator. J. Agric. Food Chem. 54:9119-9125.

7. Chan, K. Y., Van Zwieten, L., Meszaros, I., Downie, A., and Joseph, S. 2007. Agronomic values of greenwaste biochar as a soil amendment. Aust. J. Soil Res. 45:629-634.

8. Chan, K. Y., Van Zwieten, L., Meszaros, I., Downie, A., and Joseph, S. 2008. Using poultry litter biochars as soil amendments. Aust. J. Soil Res. 46:437-444.

9. Cole, L., Dewey, F. M., and Hawes, C. R. 1996. Infection mechanisms of Botrytis species: pre-penetration and pre-infection processes of dry and wet conidia. Mycol. Res. 100:277-286.

10. Conrath, U., Beckers, G. J., Flors, V., Garcia-Agustin, P., Jakab, G., Mauch, F., Newman, M. A., Pieterse, C. M. J., Poinssot, B., Pozo, M. J., Pugin, A., Schaffrath, U., Ton, J., Wendehenne, D., Zimmerli, L., and Mauch-Mani, B. 2006. Priming: getting ready for battle. Mol. PlantMicrobe Interact. 19:1062-1071.

11. Conrath, U., Pieterse, C. M. J., and Mauch-Mani, B. 2002. Priming in plant-pathogen interactions. Trends Plant Sci. 7:210-216.

12. De Meyer, G., Bigirimana, J., Elad, Y., and Höfte, M. 1998. Induced systemic resistance in Trichoderma harzianum T39 biocontrol of Botrytis cinerea. Eur. J. Plant Pathol. 104:279-286.

13. DeLuca, T. H., MacKenzie, M. D., and Gundale, M. J. 2009. Biochar effects on soil nutrient transformations. Pages 251-270 in: Biochar for Environmental Management. J. Lehmann and S. Joseph, eds. Earthscan, London.

14. Elad, Y. 1994. Biological control of grape gray mold by Trichoderma harzianum. Crop Prot. 13:35-38.

15. Elad, Y., Messika, Y., Brand, M., Rav David, D., and Sztejnberg, A. 2007. Microclimate effect on Leveillula taurica powdery mildew of sweet pepper. Phytopathology 97:813-824.

16. Elad, Y., Williamson, B., Tudzynski, P., and Delen, N. 2004. Botrytis spp. and diseases they cause in agricultural systems - an introduction. Pages 18 in: Botrytis: Biology, Pathology and Control. Y. Elad, B. Williamson, P. Tudzynski, and N. Delen, eds. Kluwer Academic Publishers, Dordrecht, The Netherlands.

17. Elad, Y., and Yunis, H. 1993. Effect of microclimate and nutrients on development of cucumber gray mold (Botrytis Cinerea). Phytoparasitica 21:257-268.

18. Elad, Y., Yunis, H., and Mahrer, Y. 1988. The effect of climatic conditions in polyethylene-covered structures on gray mold disease of winter cucumbers. Appl. Agric. Res. 3:243-247.

19. Glaser, B., Lehmann, J., and Zech, W. 2002. Ameliorating physical and chemical properties of highly weathered soils in the tropics with charcoalA review. Biol. Fertil. Soils 35:219-230.

20. Guetsky, R., Shtienberg, D., Elad, Y., and Dinoor, A. 2001. Combining biocontrol agents to reduce the variability of biological control. Phytopathology 91:621-627.

21. Hamiduzzaman, M. M., Jakab, G., Barnavon, L., Neuhaus, J. M., and Mauch-Mani, B. 2005. $\beta$-Aminobutyric acid-induced resistance against downy mildew in grapevine acts through the potentiation of callose formation and jasmonic acid signaling. Mol. Plant-Microbe Interact. 18:819-829.

22. Harman, G. E., Howell, C. R., Vitebro, R. A., Chet, I., and Lorito, M. 2004. Trichoderma species-opportunistic, avirulent plant symbionts. Nat. Rev. Microbiol. 2:43-56.

23. Hobbs, E. L., and Waters, W. E. 1964. Influence of nitrogen and potassium on susceptibility of Chrysanthemum morifolium to Botrytis cinerea. Phytopathology 54:674-676.

24. Hoitink, H. A. J., Stone, A. G., and Han, D. Y. 1997. Suppression of plant diseases by composts. Hortscience 32:184-187.

25. Iriti, M., Rossoni, M., Borgo, M., and Faoro, F. 2004. Benzothiadiazole enhances resveratrol and anthocyanin biosynthesis in grapevine, meanwhile improving resistance to Botrytis cinerea. J. Agric. Food Chem. 52:4406-4413

26. Iswaran, V., Jauhri, K. S., and Sen, A. 1980. Effect of charcoal, coal and peat on the yield of moong, soybean and pea. Soil Biol. Biochem. 12:191192.

27. Kloepper, J. W., Ruy, C. M., and Zhang, S. 2004. Induced systemic resistance and promotion of plant growth by Bacillus spp. Phytopathology 94:1259-1266.

28. Korolev, N., David, D. R., and Elad, Y. 2008. The role of phytohormones in basal resistance and Trichoderma-induced systemic resistance to Botrytis cinerea in Arabidopsis thaliana. Biocontrol 53:667-683.

29. Krause, M. S., De Ceuster, T. J. J., Tiquia, S. M., Michel, F. C., Madden, L. V., and Hoitink, H. A. J. 2003. Isolation and characterization of rhizobacteria from composts that suppress the severity of bacterial leaf spot of radish. Phytopathology 93:1292-1300.

30. Laird, D. A. 2008. The charcoal vision: a win-win-win scenario for simultaneously producing bioenergy, permanently sequestering carbon, while improving soil and water quality. Agron. J. 100:178-181.

31. Lehmann, J. 2007. Bio-energy in the black. Front. Ecol. Environ. 5:381387.

32. Lehmann, J. 2007. A handful of carbon. Nature 447:143-144.

33. Lehmann, J., Pereira da Silva, J., Jr., Steiner, C., Nehls, T., Zec, W., and Glaser, B. 2003. Nutrient availability and leaching in an archaeological anthrosol and a ferralsol of the Central Amazon basin: fertilizer, manure and charcoal amendments. Plant Soil 249:343-357.

34. Loffredo, E., Berloco, M., and Senesi, N. 2008. The role of humic fractions from soil and compost in controlling the growth in vitro of phytopathogenic and antagonistic soil-borne fungi. Ecotoxicol. Environ. Safety 69:350-357.

35. Mathews, J. A. 2008. Carbon-negative biofuels. Energy Policy 36:940945.

36. Matsubara, Y., Hasegawa, N., and Fukui, H. 2002. Incidence of Fusarium root rot in asparagus seedlings infected with arbuscular mycorrhizal fungus as affected by several soil amendments. J. Jpn. Soc. Hortic. Sci. 71:370-374.

37. Noble, R., and Coventry, E. 2005. Suppression of soil-borne plant diseases with composts: a review. Biocontrol Sci. Technol. 15:3-20.

38. Novak, J. M., Busscher, W. J., Laird, D. L., Ahmedna, M., Watts, D. W., and Niandou, M. A. S. 2009. Impact of biochar amendment on fertility of a southeastern coastal plain soil. Soil Sci. 174:105-112.

39. Ntougias, S., Papadopoulou, K. K., Zervakis, G. I., Kavroulakis, N., and Ehaliotis, C. 2008. Suppression of soil-borne pathogens of tomato by composts derived from agro-industrial wastes abundant in Mediterranean regions. Biol. Fertil. Soils 44:1081-1090.

40. Palti, J. 1988. The Leveillula mildews. Bot. Rev. 54:423 535.

41. Perazzolli, M., Dagostin, S., Ferrari, A., Elad, Y., and Pertot, I. 2008. Induction of systemic resistance against Plasmopara viticola in grapevine by Trichoderma harzianum $\mathrm{T} 39$ and benzothiadiazole. Biol. Control 47:228-234.

42. Pietikainen, J., Kiikkila, O., and Fritze, H. 2000. Charcoal as a habitat for microbes and its effect on the microbial community of the underlying humus. Oikos 89:231-242.

43. Prithiviraj, B., Perry, L. G., Badri, D. V., and Vivanco, J. M. 2007. Chemical facilitation and induced pathogen resistance mediated by a rootsecreted phytotoxin. New Phytol. 173:852-860.

44. Rajkumar, M., Lee, K. J., and Freitas, H. 2008. Effects of chitin and salicylic acid on biological control activity of Pseudomonas spp. against damping off of pepper. S. Afr. J. Bot. 74:268-273.

45. Reuveni, M., Agapov, V., and Reuveni, R. 1995. Induced systemic protection to powdery mildew in cucumber by phosphate and potassium fertilizers: Effects of inoculum concentration and post-inoculation treatment. Can. J. Plant Pathol. 17:247-251.

46. Reuveni, M., and Reuveni, R. 2000. Prior inoculation with nonpathogenic fungi induces systemic resistance to powdery mildew on cucumber plants. Eur. J. Plant Pathol. 106:633-638.

47. Schnitzer, M. I., Monreal, C. M., and Jandl, G. 2008. The conversion of chicken manure to bio-oil by fast pyrolysis. III. Analyses of chicken 
manure, bio-oils and char by Py-FIMS and Py-FDMS. J. Environ. Sci. Health Part B Pestic. Food Contam. Agric. Wastes 43:81-95.

48. Schnitzer, M. I., Monreal, C. M., Jandl, G., Leinweber, P., and Fransham, P. B. 2007. The conversion of chicken manure to biooil by fast pyrolysis II. Analysis of chicken manure, biooils, and char by curie-point pyrolysisgas chromatography/mass spectrometry (Cp Py-GC/MS). J. Environ. Sci. Health Part B Pestic. Food Contam. Agric. Wastes 42:79-95.

49. Sonneveld, C. 2002. Composition of nutrient solutions. Pages 179-210 in: Hydroponic Production of Vegetables and Ornamentals. D. Savvas and H. C. Passam, eds. Embryo Publications, Athens.

50. Steiner, C., Das, K. C., Garcia, M., Forster, B., and Zech, W. 2008. Charcoal and smoke extract stimulate the soil microbial community in a highly weathered xanthic ferralsol. Pedobiologia 51:359-366.

51. Steiner, C., Teixeira, W. G., Lehmann, J., Nehls, T., de Macedo, J. L. V., Blum, W. E. H., and Zech, W. 2007. Long term effects of manure, charcoal and mineral fertilization on crop production and fertility on a highly weathered Central Amazonian upland soil. Plant Soil 291:275-290.

52. Strezov, V., Patterson, M., Zymla, V., Fisher, K., Evans, T. J., and Nelson, P. F. 2007. Fundamental aspects of biomass carbonization. J. Anal. Appl. Pyrol. 79:91-100.

53. Swartzberg, D., Kirshner, B., Elad, Y., and Granot, D. 2008. Botrytis cinerea induces senescence and is inhibited by autoregulated expression of the IPT gene. Eur. J. Plant Pathol. 120:289-297.

54. Ton, J., and Maunch-Mani, B. 2003. Elucidating pathways controlling induced resistance. Pages 99-109 in: Chemistry of Crop Protection. G. Voss and G. Ramos, eds. Wiley-VCH, Weinheim.

55. Trouvelot, S., Varnier, A. L., Allègre, M., Mercier, L., Baillieul, F., Arnould, C., Gianinazzi-Pearson, V., Klarzynski, O., Joubert, J.-M., Pugin, A., and Daire, X. 2008. A $\beta-1,3$ glucan sulfate induces resistance in grapevine against Plasmopara viticola through priming of defense responses, including HR-like cell death. Mol. Plant-Microbe Interact. 21:232-243.

56. Vallad, G. E., and Goodman, R. M. 2004. Systemic acquired resistance and induced systemic resistance in conventional agriculture. Crop Sci. 44:1920-1934.
57. Van der Ent, S., Van Wees, S. C., and Pieterse, C. M. 2009 Jasmonate signaling in plant interactions with resistance-inducing beneficial microbes. Phytochemistry 70:1581-1588.

58. Van Loon, L. C., Bakker, P. A. H. M., and Pieterse, C. M. 1998. Systemic resistance induced by rhizosphere bacteria. Annu. Rev. Phytopathol. 36:453-483.

59. Van Wees, S. C. M., Pieterse, C. M. J., Trijssenaar, A., Vant Westende, Y. A. M., Hartog, F., and Van Loon, L. C. 1997. Differential induction of systemic resistance in Arabidopsis by biocontrol bacteria. Mol. PlantMicrobe Interact. 10:716-724.

60. Verhoeff, K. 1968. Studies on Botrytis cinerea in tomatoes. Effect of soil nitrogen level and of methods of deleafing upon occurrence of $B$. cinerea under commercial conditions. Neth. J. Plant Pathol. 74:184-192.

61. Walters, D., Walsh, D., Newton, A., and Lyon, G. 2005. Induced resistance for plant disease control: Maximizing the efficacy of resistance elicitors. Phytopathology 95:1368-1373.

62. Wardle, D. A., Zackrisson, O., and Nilsson, M. C. 1998. The charcoal effect in Boreal forests: Mechanisms and ecological consequences. Oecologia 115:419-426.

63. Warnock, D. D., Lehmann, J., Kuyper, T. W., and Rillig, M. C. 2007. Mycorrhizal responses to biochar in soil-concepts and mechanisms. Plant Soil 300:9-20.

64. Weintraub, P. G., Kleitman, S., Mori, R., Shapira, N., and Palevsky, E. 2003. Control of the broad mite (Polyphagotarsonemus latus (Banks)) on organic greenhouse sweet peppers (Capsicum annuum L.) with the predatory mite, Neoseiulus cucumeris (Oudemans). Biol. Control 27:300-309.

65. Wiese, J., Kranz, T., and Schubert, S. 2004. Induction of pathogen resistance in barley by abiotic stress. Plant Biol. 6:529-536.

66. Wiese, J., Wiese, H., Schwartz, J., and Schubert, S. 2005. Osmotic stress and silicon act additively in enhancing pathogen resistance in barley against barley powdery mildew. J. Plant Nutr. Soil Sci. 168:269-274.

67. Yermiyahu, U., Shamai, I., Peleg, R., Dudai, N., and Shtienberg, D. 2006. Reduction of Botrytis cinerea sporulation in sweet basil by altering the concentrations of nitrogen and calcium in the irrigation solution. Plant Pathol. 55:544-552. 